\title{
A Magyar Királyi Csendőrség karhatalmi fellépésének gyakorlata
}

DOI : 10.31627/RTF.XXI V.2014.39-40-41-42N.143-154P

A dualizmus időszakában a karhatalom sokkal szélesebb tevékenységi kört takart, mint amit napjaink szóhasználata lefed. A karhatalom nem jelentett egyet az ún. csapaterővel végrehajtott feladatokkal, hanem a közigazgatás müködésének olyan támogatását jelentette, melyben a legitim fizikai erőszak állami monopóliumával bíró fegyveres testületek jelenléte vagy intézkedése volt szükséges. Meg kell különböztetni a szükebb és tágabb értelmü karhatalmat. Tágabb értelemben a hatósági tevékenységek fegyveres erővel történő támogatását jelentette, míg szükebb értelemben a csapaterővel végrehajtott feladatokat. A karhatalom tehát nem volt más, mint a fenyegetett törvényesség biztosítására, a megzavart közrend helyreállítására kirendelt fegyveres erő. A szó közönséges értelmében a karhatalom olyan segítséget jelentett, amely fegyveresen jelenik meg és éppen fegyverének tekintélyével oszlatja el a törvényességet fenyegető veszedelmet és állítja helyre a megzavart közrendet.

A csendőrség tevékenységi körében az arra feljogosított hatóság vagy tisztviselö felhívására illetve kirendelésére teljesített szolgálatok között el kell különíteni a karhatalmat, a rendőri segélyt és az ezekkel rokon tartalmú, de más jogalapon nyugvó felszólítás vagy rendelkezés folytán teljesített közbiztonsági szolgálatot. E három fogalom, valamint a kusza jogszabályi szövegekben elrejtett fogalmi ismérveik hosszú időn át fejtörést okoztak a közigazgatási szerveknek. A karhatalmi tevékenység és határterületei áttekintéséhez a korabeli közigazgatási struktúra és jogszabályrendszer értékelése is szükséges, amelyet jelen tanulmány - terjedelmi korlátaira tekintettel - nem tárgyal.

\section{A Magyar Királyi Csendőrség karhatalmi fellépésének jogalapja tömeggel szemben}

Napjaink szakmai terminológiája a szükebb értelemben vett karhatalmi teendőkre nem alkalmazza a „karhatalom” kifejezést, helyette a csapaterős teendők szakzsargon terjedt el. A rendvédelem részeként a csapaterős feladatok teljesítését minden korban és országban megoldották valamilyen formában. A csapaterös rendvédelmi feladatkörre önálló testület létrehozása és müködtetése azonban kontinensünkön a kelet-európai államigazgatási modell sajátja. Elsősorban a honvédelmi alapfeladattal rendelkező testületek, mint például a haderő, a nemzetőrség, illetve egyes időszakokban és térségekben a polgárörség kaphatott csapaterős rendvédelmi feladatkört. ${ }^{1}$ A dualista Magyarországon e feladatra szintén több szervezet volt hivatva.

A Magyar Királyi Csendőrség 1881. évi Szervezeti és Szolgálati Utasítása szerint a testület feladata volt a megzavart rendet és békét helyreállítani, mely során a közigazgatási hatóságok rendelkezése alatt állt. Azok hivatalos felszólitásainak feltétlenül engedelmeskedni tartozott és a felhívás megbírálásába nem bocsátkozhatott. A meghagyás vagy meghívás tartalmáért mindenkor az azt kiadó hatóság vagy egyén volt felelős, ahogy ezek foganatosításáért, valamint eközben a törvények és szolgálati utasítás határozványainak pontos betartásáért az eljáró csendőr. ${ }^{2}$ A csendőrség lényeges vonása - amely megkülönböztette más rendvédelmi szervektől és föképp a rendőrségtől — a fentiek alapján a társ rendvédelmi testületekétől eltérő kompetenciája volt. A dualizmus kori rendőrségek önálló hatósági jogkörrel rendelkeztek. Ezzel szemben a Magyar Királyi Csendőrség feladatát a közigazgatási intenciók megvalósításának biztosítása képezte. A csendőrség azonban szolgálatellátás során szembetalálta magát olyan élethelyzetekkel, amikor a közigazgatási hatóságok intelmeit nélkülözve is el kellett járnia. Ezeket nevezeték az úgynevezett rendes szolgálat körébe tartozó feladatoknak. A Magyar Királyi Csendörség tehát olyan rendvédelmi testület volt, amelyet azzal a céllal hoztak létra, hogy a közigazgatási döntések végrehajtását szükség szerint ki is kényszerítse akár fizikai erő, kényszerítő intézkedések, végső soron fegyverhasználat által is. ${ }^{3}$

Nemcsak a kompetencia, hanem a karhatalmi igénybevétel tekintetében is lényegesen eltért a csendörség korának többi rendvédelmi szervezetétől. Egyrészt a csendőrség katonailag szervezett örtestület volt, ami azt jelentette, hogy a csendőr személyében katonának minősült, katonai rangot viselt, és a személyi állomány függelmi viszonyai is katonaiak voltak. Az állomány felkészültsége tartalmazta a csapaterős karhatalmi alkalmazásra vonatkozó ismereteket, ami katonai kiképzésen és a kötelékben végrehajtott harceljárások ismeretén alapult. Az egyéni fegyverzet szintén alkalmassá tette a személyi állományt a csapaterős fellépésre. ${ }^{4}$ A mai szemmel radikálisnak tủnő szuronytámadás és löfegyverhasználat kapcsán szükséges megjegyezni, hogy a kirendelt karhatalom fellépése a rendelkezésére álló felszereléshez igazodott, amely katonai volt. Ennek megfelelően katonai taktikát alkalmaztak és gyalogsági (vagy épp lovassági) kötelékharcként értelmezték a rendvédelmi fellépést. Természetesen itt a fellépés célja nem az ellenség megsemmisítése volt, hanem a közrend helyreállítása és a tömeg szétoszlatása. Ez a felfogás megfelelt a korabeli Európa rendvédelmi 
gondolkodásának, hiszen a francia csendőrségnél is csak 1929-ben merült fel a gumibot rendszeresítésének kérdése. ${ }^{5}$

A dualista közigazgatási felfogás fontos eleme volt, hogy nem különültek el élesen a rendvédelmi szervezeteknek, illetve a haderő csapatainak karhatalmi teendői, hiszen a Magyar Királyi Csendőrség és a hadsereg által megvalósított karhatalmi teendők közötti fontos gyakorlati különbség az volt, hogy míg a haderö által a karhatalmi teendők végzésére vezényelt személyi állomány a közigazgatási tisztviselők mellé csak olyan számban volt biztosítható, hogy a feladat megoldására minden körülmények között képes legyen — vagyis legalább raj, de inkább szakasz erőben —, addig a csendőri karhatalom kisebb egységekre is széttagolható volt. A haderö által kivezényelt karhatalmat mindig tiszt irányította és az egyes katonák önálló intézkedési jogkörrel nem rendelkeztek, míg a csendőrségi karhatalom a csendőr járőr cselekvési szabadságát élvezte. Ez a gyakorlatban azt jelentette, hogy a haderő karhatalmi feladatok teljesítésére vezényelt személyi állománya előtt elkövetett kihágásra az észlelők nem intézkedhettek, míg a csendöröket intézkedési kötelezettség terhelte. $^{6}$

A csendőrség teljes megszervezése után ez egyre kevésbé volt jellemző, azonban folyamatosan megjelent. A katonai feladatok közbiztonsági megfelelőjeként kezelt csapaterős karhatalmi tevékenység szabályozására elsősorban a honvédelmi miniszter intézkedett, míg a polgári hatóságok részéről történő kirendelés módjára, a költségek viselésére a igazságügy- és belügyminiszter.

$\mathrm{Az}$ első átfogónak tekinthető szabályozást a honvédelmi miniszter 1876. évben körrendelet formájában adta ki. A körrendelet mellékleteként publikált Utasítás, melyben első ízben tartalmazott pontos szabályozást a hatóságok és a katonai parancsnokságok számára egyaránt. ${ }^{7}$ A rendelet módosítására és átdolgozott újbóli kiadására a honvédelmi miniszter 1886 . évben kiadott körrendeletében került sor 1887. I. 16-ai hatállyal. ${ }^{8}$ A szabályozás újabb módosítására és jelentős kiegészítésére a honvédelmi miniszter 1896. évben kiadott újabb utasításával került sor. ${ }^{9}$ Ez fontos és a polgári állam szellemiségét erősítő rendelkezést tartalmazott, miszerint a haderő csapatai a továbbiakban csak akkor voltak igénybe vehetők, ha az összpontosított csendőri erő nem volt elégséges. Kijelenthető tehát, hogy a karhatalmi csendőri erő olyan mértékben értékelődött fel az 1876-os és 1886-os utasítások óta, hogy azt már a csapaterős karhatalmi feladatok elsődleges végrehajtójának tekintették. Szükséges volt azonban szem elött tartani azt is, hogy nagyobb területet érintő vagy súlyos fegyveres harcot igénylő esetekben továbbra is a haderő kirendelt alakulatai voltak a karhatalmi teendők megvalósítói a közrend helyreállításának elsődleges eszközei.

Bár a szabályozás fejlödött és erősödött, Magyarországon a csendőrség csapaterős tevékenységeinek folyamatos tervezésére és előkészítésére csak a két világháború között került sor. Kezdetben elsősorban a csendőriskolák tanszázadai voltak ilyen jellegü feladatokra igénybe vehetők. ${ }^{\mathbf{1 0}} \mathrm{Az} \mathrm{I}$. világháború során kialakított csendör zászlóaljat a CSERNY-különítmény fegyverezte le a Tanácsköztársaság alatt. Később a II. világháború alatt hoztak létre ilyen zászlóaljakat kifejezetten csapaterős tevékenységek ellátására, például a Galántai-zászlóaljat. ${ }^{11}$

A magyar állam polgári fejlődésének az időszakában más karhatalmi formációkkal is kísérleteztek. Az államosított rendôrségen belül hoztak létre a húszas évek kezdetén csapaterős feladatok ellátására alkalmas szervezetet. ${ }^{12}$

A fentiek alapján kijelenthető, hogy a dualizmus korában a csapaterős karhatalmi feladatok ellátására nem hoztak létre állandó kötelékeket, hanem a jelentkező feladatokat ideiglenes összpontosításokkal kezelték. A legnagyobb mérvű erőkoncentráció, amelyet a dualizmus időszakában kialakítottak az a zászlóaljnyi erő volt. Ennek létszáma minden bizonnyal nem haladta meg a 300 főt, ami a korabeli 33378 főnyi rendvédelmi létszám elenyésző részét, $0,80 \%$-át tette ki. ${ }^{13}$

Háborús vagy azt megelőző időszakokban azonban a csendőrség nagyobb erőkoncentráció létrehozására is képes volt. Bosznia-Hercegovina annekcióját megelőzően a szerb ajkú területek 700-800 főnyi csendőrségi állományát például elővigyázatossági okokból 2500 főre emelték. ${ }^{14}$ Ez persze más területek közbiztonsági erejének gyengítését jelentette, ami az akkori létszámviszonyokat figyelembe véve jelentős elvonásokat is eredményezhetett. A csendörség létszáma viszont csak lassan követte a megnövekedett igényeket, bár az 1914 júliusi 9621 fős (ebből 266 tiszt) létszám 1918 októberig 12 ezer före (ebböl 287 tiszt) nőtt. ${ }^{15}$

A Magyar Királyi Csendőrség tehát - hasonlóan más európai csendőrségekhez - a francia csendőrség mintáját követte, annak a nemzeti sajátosságokra adaptált változatát képezte. Nem az eltérő vonások voltak a dominánsak, hanem az azonosságot képviselő jellemzők. ${ }^{16}$ A magyar csendőrség tevékenységében is elsődleges volt a megelőző jellegű szolgálatellátás, a megszokottól eltérő rendkívüli helyzetekre való reagálást pedig ideiglenes kötelékekkel valósította meg. Ezzel a gyakorlattal 
később maguk a franciák szakítottak, amikor a Mozgó Köztársasági Gárda megszervezésével — melynek keretében a szakasz erejü állandó bevetési alakulatokat hoztak létre - elsősorban az iparvidékek karhatalmi teendőit látták el.

Külön említést érdemel a lovassági karhatalmi fellépés, amely minden honvédségi és csendőrségi szabályzó szerint hatásos eszköz volt a felbőszült tömeg féken tartására. Kezdetben a honvéd lovasságot is előszeretettel alkalmazták erre a feladatra. Ilyenkor a fegyvernem békeállományú századai egy-egy szakaszt alakítottak és négy ilyen szakaszból szerveztek egy bevethető századot. ${ }^{17} \mathrm{~A}$ karhatalmi feladatok támogatására később minden csendőr kerület-parancsnokság alárendeltségében lovas alosztály jelent meg, melyet sikeresen alkalmaztak. A lovasság kiválóan alkalmas volt arra, hogy tereket fegyveres erőszak nélkül kiürítsen, azonban mindig zárt alakzatban kellett alkalmazni és a szétoszlatott tömeget nem szabadott üldözni. Fontos lovassági feladat volt továbbá, hogy járörözés által a tömeg gyarapodását megakadályozza.

A karhatalmi szervezetek és tömegkezelési feladatokra igénybe vett szervezeti elemek után azokat a társadalmi viszonyokat is szükséges áttekinteni, melyek között a karhatalmi rendfenntartás megvalósult. A korabeli szakmai terminológia szerint meg kell különböztetni sztrájkot (vagy egyszerü bérharcot), általános sztrájkot és forradalmi sztrájkot, amely nem a munkaadó, hanem az állam ellen irányult. ${ }^{18}$ Fontos megjegyezni, hogy az akkor uralkodó közigazgatási felfogás szerint a csendőr volt az, aki a katonasággal karöltve hivatva volt a követeléseit helytelen alapon elöadni akaró népet felvilágosítani. A SZUT szerint a csendőr „kiváló figyelmet fordítson” a munkásosztály által előidézhető mindazon eshetőségekre, melyek a közcsend és rend háborítását vonhatnák maguk után. Figyeljen fel a gyárak környékén kialakuló minden nagyobb csoportosulásra és a körülményekről azonnal tegyen jelentést a közigazgatási hatóságnak. ${ }^{19}$

A szakirodalom külön foglalkozott a nemzetiségi mozgalmak kérdésével. Mivel külföldi lázító cikk esetén a röpirat vagy újság lefoglalását az ügyészség rendelhette el, ha a csendör ilyennel találkozott, egy példányt haladéktalanul megküldött a hatóságnak. A csendőrségi joghatóság kiterjedt azonban a nyilvános szónoklatokra, melyek lázító tartalma esetén a csendőr a felszólalótól a szót megvonhatta és a beszéd folytatása esetén elfoghatta. Ilyen esetekben óvatosan, és a tömeg hangulatának megfelelő tapintattal kellett eljárni. ${ }^{20}$

$\mathrm{Az}$ anarchizmus szintén új és terjedő jelenség volt a századforduló elött. Az anarchista tanok művelői a hatóságok megfigyelései szerint Magyarországon a kézműves osztályból kerültek ki, ezért a csendörségnek kiemelt figyelmet kellett fordítania a külföldet is megjárt iparosokra és kézmüvesekre. ${ }^{21} \mathrm{Az}$ állam valós fenyegetésként értelmezte az anarchizmus terjedését, amelyet valamennyi rendelkezésére álló eszközzel kontrollálni próbált. A külföldi anarchisták ellen többek között a „külföldieknek a Magyar Koronai országai területén való lakhatásáról” szóló törvénycikk nyújthatott védelmet, mely szerint minden külföldinek 24 órán belül jelentkeznie kellett a lakóhelye szerinti állami szervezetnél. ${ }^{22}$

A veszélyekről a csendőr a hatóság kirendeléséből vagy saját észlelése által szerezhetett tudomást, és bár a szervezet alapvető rendeltetése a polgári hatóságok rendelkezéseinek végrehajtása volt, mégis szükséges volt a csendőrség számára támpontokat adni az önálló intézkedéshez. A SZUT magyarázatára kiadott segédlet szerint a közbiztonságot zavaró csoportosulás vagy zsidóellenes tüntetés, szociális zavargás, sztrájk esetén a csendőr azokat, akik a gyülekezés helye felé közelednek eltávolíthatta, az összegyült tömeget pedig parancsoló hangon szétoszlásra szólította fel. ${ }^{23}$ Természetesen a lehető legrövidebb időn belül az esetet jelenteni kellett a közigazgatási hatóságnak és a tisztviselő kiérkezését követően az általa meghatározottak szerint kellett fellépni. Komoly garanciális szabály volt azonban, hogy ha az egységet polgári tisztviselő vezette, az csak az intézkedésekkel elérni kívánt célt jelölhette meg, a végrehajtás módjára nem adhatott utasítást. Ez biztosította, hogy a karhatalmi fellépés mindig szakmai szempontok szerinti arányossággal történjen.

A professzionális karhatalmi fellépés kellő elméleti alapokkal is rendelkezett, hogy az intézkedö csendőr felismerje a veszélyes helyzeteket és a megfelelő eljárásokat foganatosítsa. A korabeli értelmezés szerint nagyobb embertömeg alatt a 100-200 fös tömeget kellett érteni. Veszélyessé akkor vált a csoportosulás, ha a tömeg valakit megtámadott vagy ezzel fenyegetett. ${ }^{24}$ Ez általában sztrájkok és tiltakozó jellegü megmozdulások esetén volt irányadó. A fentiektől meg kellett különböztetni a „csődülést”, amely a kíváncsi nép összegyülését jelentette és általában békés szemlélődésből állt. Természetesen ez is szükségessé tette a tömeg kezelését, de csak a közlekedési útvonalak szabadon tartását és a nézelődök bizonyos területre terelését és ott tartását jelentette. ${ }^{25}$

A gyakorlati karhatalmi fellépés szempontjából két legfontosabb fogalom a föcinkos és a felbujtó voltak, mivel az esetleges fegyveres erőszak alkalmazásának rájuk kellett irányulnia, így felismerésük 
és elhatárolásuk alapvető kérdés volt. Főcinkos az volt, aki a gyülekezésben a vezér szerepét játszotta és erőszakos magatartást tanúsított. Felbujtó az volt, aki csupán szóval bátorította a népet az erőszakoskodásra vagy lázító beszédet mondott.

\section{Karhatalmi felderítés, megelőzés és felkészülés}

A dualizmus korának polgári gondolkodására jellemzően a karhatalmat megelőző és elrettentő jellegü szolgálatként értelmezte a csendőrség. A szabályzatok és jogszabályok rendelkezésein túl a karhatalomként kivonultatott csapaterő megjelenése is ezt támasztotta alá, hiszen az útba indító parancsnok a felszerelések meglétén és használhatóságán túl a kifogástalan ruházatról is meggyőződött. Elvárás volt a legénység minden tagjával szemben, hogy a csapaterős alkalmazáshoz újszerü zubbony, kalap és tiszta kesztyü álljon rendelkezésére, valamint legjobb kardbojtját viselje. A csendőr tehát elsősorban megjelenésével kívánta elérni a kivonulás célját, nem pedig erőszakkal.

Ennek megfelelően a felderítés és a karhatalmi felkészülés is nagy hangsúlyt és részletes szabályozást kapott. Külön említést érdemel, hogy míg a végrehajtás gyakorlati kérdéseivel a csendőrségi szabályzatok is foglalkoznak, a karhatalmi felderítés és megelőző intézkedések elsősorban a honvédségi szabályzatokban jelennek meg. A karhatalom fogalma a katonai terminológiában is olyan csapatokat jelentett, melyeket a közhatóságok támogatására olyan célból rendeltek ki, hogy ezek hivatalos intézkedéseit és az eröszakos ellenállás leküzdését anyagi erővel támogassák. ${ }^{26}$ Katonai karhatalmat általában a hadsered (esetleg a hadtengerészet) rendelt ki, a honvédség pedig csak kivételesen és olyan esetekben, amikor a hadsereg ereje az adott területen nem állt rendelkezésre vagy elégtelen volt.

Alapvető szabály volt, hogy minden karhatalmi kötelék olyan erős legyen, hogy feladatának sikeres megoldása, valamint a fegyver becsületének megóvása minden körülmények között biztosítva legyen. A karhatalmat mindig éles lőszerrel kellett ellátni, sőt a tartalék lőszereket is ki kellett adni a személyi állománynak. A konkrétabb veszély megjelenéséről a Szabályzat a következők szerint rendelkezik: „Valamely fölkelés vagy lázongás megakadályozására vagy elfojtására, a közigazgatási hatóságok kérelmére és ezekkel egyetértöleg oly katonai intézkedések teendök, melyek a törvényes hatóságoknak rendelkezéseik kivitelére erkölcsi és anyagi erőt, biztos támaszt és elegendö hatalmat nyújtanak.",27

A honvéd és csendőr-parancsnokságok azonban saját belátásuk szerint megelőző jelleggel olyan rendszabályokat vezethettek be, amelyek az azonnali karhatalmi fellépéshez szükségesek voltak. ${ }^{28} \mathrm{Ha}$ a parancsnok készülő zendülés elöjeleit látta, akkor intézkednie kellett a csapatok összpontosított elszállásolására, és arra, hogy a tisztek lakásait a csapatuk közvetlen közelében jelöljék ki. Az erődítményeket és más katonailag fontos pontokat védelmi állapotba kellett helyezni és a parancsnokukat fontosabb ok nélkül nem lehetett felváltani. Az ilyen pontokhoz vezető utakat valamint a föközlekedési utakat a rajtaütésekkel szemben biztosítani kellett, ami tipikusan csendőrségi feladatnak volt mondható. A katonai helyőrség többségét ezen felül megfelelő szállító eszközökkel és élelemkészletekkel készenlétben kellett tartani. A helyőrségi örszolgálatot meg kellett erösíteni és szükség esetén az egész helyőrség együtt tartása volt elrendelhető. Az ilyen helyzetben bármilyen feladatra kivonuló csapatok mindig teljes felszereléssel és éles lőszerrel kerültek ellátásra.

A legénység kijárást csak nagyobb csoportokban engedélyezték és a lakossággal történő érintkezését ellenőrizték. Ez a szabály a hadsereg sorozott állományánál indokoltabb volt, azonban a csendőrök befolyásolását és a lázítók általi megkörnyékezését szintén komolyan vették. A megelőző időszakban a járőröket nagyobb erővel és lehetőleg a honvédségnél tiszt, a csendőrségnél altiszt vagy tapasztalt járörvezető vezetésével küldték ki. ${ }^{29}$

A fenti intézkedéseket a müködése során szerzett információk alapján a csendőrség már akkor megtehette, amikor a polgári hatóságok még nem igényelték karhatalomkénti fellépését. Egy szociális indíttatású lázongás vagy erőszakba torkolló sztrájk elfojtásának életciklusát tehát legalább három szakaszra bonthatjuk, melyek közül az első és az utolsó katonai jellegü, míg a második közigazgatási intézkedéseket foglal magában. Az információgyüjtés alapján bevezetett megelőző intézkedések az esetlegesen kirendelt karhatalmi erö harckészültségét voltak hivatottak fenntartani.

Amint az események látható formát öltöttek és a tiltakozók az utcára vonultak, a polgári hatóság elsősorban csendőrségi - karhatalmat rendelt ki, amely felett saját tisztviselöje rendelkezett. Ennek jogalapja a SZUT „Karhatalmi utasítás” címü szakasza volt, mely szerint ha az eljárásnál nyomós adatok alapján ellenszegüléstől kellett tartani, vagyis a tömeg jogellenes magatartást tanúsított és a polgári tisztviselő felszólítására szétoszlani nem akart, úgy a hatóság vagy annak eljáró tagja a csendőrség támogatását vehette igénybe. ${ }^{30}$ Az utasítás szerint népgyüléseknél vagy csődüléseknél a 
csendőrség a közigazgatási hatóság különös utasításai szerint járt el. Ha közbelépni volt kénytelen mindenek előtt a „törvény nevében” szavakkal felhívta a résztvevőket a szétoszlásra, mely eredménytelensége esetén a „főtényezőket” eltávolította. ${ }^{31}$ Az eseményeknek ebben a szakaszában a polgári tisztviselő háttérbe vonult és a törvényes rend helyreállitásáig a karhatalom parancsnoka vette át az irányítást. A lázongás elfojtásához szükséges intézkedéseket tehát a parancsnok tisztán katonai szempontok alapján vezette be és a Magyar Királyi Honvédség Szolgálati Szabályzatának I. rész 72. §a szerint kellett eljárnia. ${ }^{32}$

A közigazgatási hatóság képviseletét a csendőrségi karhatalmi erő mellett az alkalmazott létszám határozta meg: míg kisebb járőr erejü karhatalmi csoport mellett rendőri közeg jelenléte is elégséges volt, addig nagyobb csapat mellett rendőrkapitány vagy vezető tisztviselő megjelenése volt szükséges. Közigazgatási tisztviselő vagy rendőr jelenléte nélkül a katonai karhatalmi erő - ha csak súlyos erőszakos cselekményeket nem tapasztalt - nem intézkedett, a csendőrkötelék viszont saját kezdeményezésre is intézkedésbe kezdhetett, ha ez a karhatalmi célt nem veszélyeztette. A kirendelt karhatalmakra azonban egységesen elmondható volt, hogy amennyiben a kirendelő hatóság közege indokolatlan és tartósan távol volt, a karhatalom további utasításig bevonult osztagához. A karhatalom a közeg intézkedését nem bírálhatta, de ha a szolgálati utasítás 29. § (3) bekezdésében foglaltak nyilvánvalóan fennálltak, az együttmüködést kivételesen megtagadhatta.

A tisztviselő tehát kulcsszerepet játszott a karhatalmi fellépéskor, ezért mindenkor meg kellett győződni a tisztviselő személyének hitelességéről. A karhatalom alkalmazása előtt tehát - szükség esetén távbeszélő vagy távíró igénybe vételével -meg kellett győződni a kirendelő tisztviselő megbízásának valódiságáról. A konkrét alkalmazásra a kirendelő hatósággal egyetértőleg tervezetet kellett készíteni. ${ }^{33}$ A hatóság nevében eljáró tisztviselö biztonságának garantálása volt a karhatalom egyik legfontosabb feladata, ezért a csapattal tartó közeg mellé külön járőrt kellett kirendelni.

\section{Tömegkezelés}

A korabeli szakmai követelmények szerint az összpontosításoknál a parancsnoki feladatok elsősorban a legénység pontos létszámának ismeretét, az elhelyezésről és élelmezésről történő gondoskodást, valamint a szolgálati feladatokra történő kiképzést, felkészítést, és a szolgálati beosztás elkészítését foglalták magukba. A karhatalom parancsnoka az alkalmazás előtt gondosan felmérte a helyszínt és a várható feladatot, majd ehhez igazította a rendelkezésre álló erő elosztását. Fontos követelmény és szakmai alapelv volt, hogy a parancsnok a müködési területre 1-2 nappal az alkalmazás előtt szálljon ki, ahol szükség szerint informálódjon a helyi hatóságoktól. A terep bejárása után készítsen vázlatrajzot, hogy a csapat felvezetése és a járőrök elosztása előtt tiszta képet kapjon a területről. A módszertan napjainkig sem változott és a helyszínbejárás legcélszerübb gyakorlati fogásait már a századfordulón alkalmazták.

A helyszín adottságainak felmérése után a rendelkezésre álló erő elosztása következett. A szolgálati beosztást (szakasz erőnél) a következők szerint készítette el és hirdette ki a karhatalmi parancsnok: A felsorakoztatott szakaszból kiléptette az altiszteket és altiszti vizsgát tett személyeket, majd a járőrvezetőket, végül a csendöröket is, és így (a helyben maradó próbacsendőrökkel együtt) négy csoportot alakított meg. Minden csoportból kiválasztotta azokat, akik a helyi viszonyokat és a területet ismerték. Ezután úgynevezett tagpárokat alakított ki egy altisztből, egy járőrvezetőből, egy csendőrből és egy próbacsendőrből. Mindegyik kialakított 4 fös csoportba legalább egy korábban kijelölt, a környéket ismerő személy került. A tagpárt vezető altiszt feljegyezte a hozzá beosztott csendörök neveit, majd visszaálltak a szakaszba. Ennek az volt a legnagyobb elönye, hogy az elöre kijelölt tagpárokat azonnal külön feladatra lehetett küldeni az alkalmazás során. A szolgálati fegyelemre és a karhatalmi fellépés közbeni parancsnoki kontrollra is jó hatással volt a módszer, mivel minden altiszt csak három beosztott csendőr intézkedését felügyelte. A parancsnok már itt kiválaszthatta azokat a rátermett csendőröket, akiket a föcinkosok és felbujtók kiemelésére kívánt küldeni. ${ }^{34}$

Az eligazítás során a parancsnok a vázlatrajz segítségével bemutatta a terepet és kijelölte a főbb tereptárgyakat és helyszíneket. Ha kellő idő állt rendelkezésre az alkalmazás előtt az altisztekkel együtt is bejárhatta a helyszínt. A vázlatrajzon meg kellett jelölni az egyes járőrök felállítási helyét, a tartalékként kikülönített legénység felállítási helyét és létszámát, valamint a gyülekező és a parancsnoki állás helyét is.

A járöröknek és különítményeknek meg kellett hagyni, hogy amint a felállítási helyet indokoló szolgálati ok megszünik, minden további parancs nélkül vonuljanak a gyülekező helyre. A szolgálati 
feladatok végrehajtásának folyamatos ellenőrzésére a parancsnok 2-3 altisztet jelölt ki, akik a csoportokat és járőröket visszatérően ellenőrizték.

Fontos, hogy az összpontosított erőket - még a közigazgatási tisztviselők kérésére is - tilos volt elbújtatni és azt a látszatot kelteni, hogy csendőri biztosítás nincs jelen. Ezzel ugyanis nem volt elérhető az összpontosítás célja, vagyis a tömeg visszatartása az eröszakos cselekményektől, amelyre végső soron valamennyi intézkedés irányult. ${ }^{35}$

Az alkalmazás alapvető formája a sorfal és a mozgósorfal voltak. A csendőrségi karhatalmi tevékenységet is alapjaiban meghatározó honvédségi Szolgálati Szabályzat megfogalmazása szerint a sorfalak célja az volt, hogy ünnepségeken és egyéb nagyobb tömegeket vonzó alkalmakkor bizonyos területeket elkülönítsen és a közlekedésre szabadon tartson ${ }^{36}$ A sorfalhoz kirendelt eröt rendszerint két sorban, megfelelő térközökkel állították fel. A sorfal biztosítási jellegü formáció volt, amelynek higgadtságot és az erőt kellett sugároznia az összegyült tömeg felé. A szabályzat külön kiemelte, hogy a sorfalak kordonparancsnokai minden hangoskodás és felesleges szaladgálás nélkül tartsák fenn a rendet osztagaik körében és ahol kell támogatólag vagy oktatólag lépjenek közbe. ${ }^{37}$

A sorfal ideális alakzat volt a tömeg viselkedésének rugalmas követésére és lehetöséget adott mozgásra, kiszorításra, esetleg járőrök kiküldésére is. Rendeltetése mégis békés jellegü volt, a tömeg körülhatárolására, a közlekedés biztosítására és a fegyveres erő jelenlétének demonstrálására szolgált. A tömeg dinamikáját a megelőzés primátusának figyelembe vételével követte. A Szolgálati Szabályzat szellemében „A tolongás megakadályozásnál lehetöleg kímélettel és tapintattal kell eljárni, de mégis semmit sem türni, ami a vett utasitásokkal ellenkezik!", ${ }^{38}$ vagyis a rendezvény kordában tartása volt a cél. Ezt támasztja alá az is, hogy a sorfalhoz alkalmazott (honvéd) legénység hátbőrönd nélkül vonult ki, a lőfegyvert pedig rejtett szuronnyal vállra vagy lábhoz állásban tartotta, vagyis nem harcfeladatra készült. Fontos, hogy a sorfal csak templomon kívül az oltári szentség közeledésekor valamint Ö Felsége és a Felséges uralkodó ház tagjai előtt teljesített tiszteletadást imához állással, illetve fővetéssel. A mozgó sorfal tiszteletadást nem teljesített. ${ }^{39}$

Ha a várható feladat inkább tömegoszlatási, mint biztosítási jellegü volt, a sorfal elhelyezését megváltoztatták a helyszín lehetőségeinek függvényében. Fő szabály szerint az embertömegtől a csendörség 10-20 lépésnyire állt fel, hogy a tömeget szemmel tarthassa és támadás esetén ideje legyen védekezni. Arra törekedtek, hogy hátuk mögött házfal vagy más akadály legyen, hogy onnan a csapatot támadás ne érhesse. Ha ez nem volt lehetséges és a tömeg a csendöröket körülfogta, egymásnak háttal állva vettek fel védekező pozíciót.

A SZUT összefoglalása szerint ha a nagyobb embertömeg által okozott és veszélyes jelleget öltött rendzavarás alkalmával az illetékes hatóság a csendőrséget segédletül felhívta, vagy ha másképpen tudomására jutott, az összes legénység az őrsparancsnok vezénylete alatt a rendzavarás színhelyére kivonult és megfelelő távolságban az embertömegtől, lehetőleg fedett háttal felállt. ${ }^{40} \mathrm{~A}$ karhatalom parancsnoka (a fentiek szerint legtöbbször az örsparancsnok) szükség esetén harsány hangon a „törvény nevében" szólította fel az embertömeget a szétoszlásra és arra, hogy támadásuk esetén fegyvert fog használni. A parancsnok ezután csendőröket jelölt ki, hogy a népet támadásra buzdító személyeket kiemeljék és elfogják, vagy a korábban erre kiválasztott tagpárt küldte ki. A kiküldött csoportot úgy kellett eligazítani, hogy a kiemelés után a hangadókat kísérö csendőrök helyezzék fegyverüket lőkész helyzetbe és ügyeljenek, hogy a tömeg az örizetbe vett személyeket ne bánthassa.

A kiemelést a parancsnok „Szuronyt szegezz! Elöre indulj!” vezényszavai után, az elrendelt szuronytámadás közben kellett végrehajtani, mivel ilyenkor a tömeg kimozdult helyzetéből. Fontos, hogy akik a szurony elől nem akartak kitérni vagy távozni, azok a hatóságok és a közcsend elleni kihágást követtek el, így őket el kellett fogni, nem pedig megsebesíteni. A legfontosabb feladat az volt, hogy a lázongás szervezői kézre kerüljenek, ezért az erre kikülönített járőr az oldal irányból végrehajtott „kiemelés” után az elfogottak személyleírását, az elfogás körülményeit valamint az elfogásban résztvevő csendőrök neveit feljegyezte, hogy a későbbi eljárásban az adatok rendelkezésre álljanak. Ezeket a csapattal kirendelt hatósági tisztviselőnek később átadták. ${ }^{41}$

Ha a tömeg a fentiek miatt köveket dobálva vagy egyéb módon felfegyverkezve támadt a csendőrökre újra fel kellett őket szólítani a fegyverhasználatra. Ha ez már nem volt lehetséges a parancsnoknak tüzet kellett vezényelnie az ellenszegülö néptömegre. ${ }^{42}$ A fegyver használata, vagyis a gyalogság szuronytámadása illetve a lovasság rohama előtt lehetőleg a kivonult kürtösökkel a „roham” jelet, lőfegyverhasználat elött az „arcirányból takarodás” jelet kellett fújatni, amitől szintén az erőszak megelőzősét és a tömeg visszarettentését várták. A kürtjel egyrészt jelzés volt a tömegnek, hogy a karhatalom rövidesen fegyvert használ, másrészt az ellenszegülő katonaviselt férfiak felismerve a kürtjeleket jobb belátásra térhettek. 
A lázongó néptömeg szétszórása előtt tehát több felszólításnak kellett elhangoznia. Csak ha ezek eredménytelenek maradtak, akkor kerülhetett sor a gyalogság szuronytámadására és a kiemelés megkísérlésére. Ha ez nem volt elégséges, a csapatra tüzeltek, vagy másként önvédelemre kényszerítették, akkor lőfegyvert kellett használnia. Ez alakalommal azonban nem szabadott vaklőszerrel vagy a levegőbe löni.

Ha a csendőrség visszavonulni volt kénytelen, azt „,csatározó módon” kellett tennie, vagyis az egyik sor jól irányított egyes lövésekkel fedezte a másik sor visszavonulását.

Többször szóba került már a különítmények és kiküldött járőrök kérdése, melyre szintén léteztek szakmai ajánlások. A különítmények olyan csapatrészek voltak, melyek csapattestüktől ideiglenesen elkülönítve, különös szolgálati rendeltetéssel bírtak. ${ }^{43}$ Különítményeket csak akkor küldhettek ki az alkalmazás helyének környékére, ha ezáltal a fö karhatalmi erő nem gyengült meg. A kisebb kötelékekböl éppen ezért a kikülönítéseket nem ajánlották.

A laktanyáján kívül összevont karhatalmat tilos volt házanként elszállásolni, inkább nagyobb épületekben, egy helyen. A közös elhelyezés körletében éjszakai ügyeletet kellett szervezni. Szükség esetén az elszállásolt különítmény azonnal a gyülekezésre kijelölt riadótéren gyülekezett. Így biztosították a harckészültség fenntartását az ideiglenes elhelyezésben és az elszállásolt csapat védelmét támadás esetén.

\section{Szuronyharc}

A közbiztonsági szuronyharc talán a legellentmondásosabb taktikai eljárása volt a századfordulós Európa rendvédelmi testületeinél. A második világháborút követően nem alkalmazott harceljárás gyökerei a katonai szuronyharcban keresendők, azonban ennek továbbfejlesztett változatát fedezhetjük fel benne. Az alapvető katonai fogások három részre oszthatók, úgy mint szurony-, kard- és lovasság elleni technikákra.

A gyalogság elleni helyezkedésnél a katona egy negyedrész fordulatot tett jobbra, bal lábát erős, rövid, hallható lépéssel maga elé a földre helyezte, térdeit behajlította. A felső test eközben egyenes maradt és a test súlya a jobb lábon nyugodott. A NAPÓLEON utáni időkben ezt ,alant állás”-nak nevezték. ${ }^{44}$ Bár a szurony eltűnt a közbiztonsági szolgálatból, örökségét hosszú ideig őrizték a csapaterős karhatalmi feladatok. Még a közelmúltban is találkozhattunk például olyan tömegoszlatásokkal, melyeket a kiérkező kötelék a felállítási helyek elfoglalását követően erős bal lábas „toppantással” kezdett meg. Ez az alant állás, majd a későbbi szuronyt szegezz állás napjainkig örzött maradványa, amely - akárcsak egy évszázaddal ezelött - a mozzanat tömegre gyakorolt pszichológiai hatását igyekezett kihasználni.

A kard elleni helyezkedésnél a testsúlyt bal lábra kellett helyezni, a puskát pedig keresztben a test elé tartani. ${ }^{45}$ Ez lett a későbbi közbiztonsági szuronyharc alapállásának elődje. A „Vívni állás” vezényszót később a csendőrségnél is használt „Szuronyt szegezz” vezényszó váltotta fel. ${ }^{46} \mathrm{~A}$ szabályzatok és vezényszavak változása a szuronyfegyver jelentőségének csökkenésével és közbiztonsági fegyverré válásának folyamatával párhuzamosan zajlott. A szuronyvívás alapállása tehát a „vívni állás” maradt, amelyre a katona bal lábát egyenesen előre helyezi, jobb lábát fél lépésnyire hátra húzza és a fegyvert a „Szuronyt szegezz” vezényszónak megfelelően tartja. A testsúly mindkét lábra egyformán van elosztva. ${ }^{47}$

A lovasság elleni helyezkedéskor az alapállásból a jobb lábat oldalra és hátra helyezve a testsúly a bal lábon nyugodott. A lovas elleni küzdelem alapja az volt, hogy a katona jobb lábbal hirtelen előre és oldalt lépett, a testsúlyát a jobb lábára helyezte át (jobbra ugrás) ezáltal a mellette elhaladó lovas bal oldalára került, aki így a kardját csak nehezen tudta használni. A katona mindig igyekezett a ló farához közeledni és innen a lovas oldalát megtámadni. Ezt a kör alakú hátra futást „körlésnek” nevezték. Fontos, hogy a katona soha nem támadhatta a lovat, mivel az rá is veszélyes volt. ${ }^{48}$

A védekezések vonatkozásában tehát meg kell különböztetni a szurony-, a kard- és a lovassági lándzsa (dzsida) elleni védekezés technikáit. A szurony ellen a puskát bal kézzel felemelve a tust jobb kézzel a csípő elé tartva védekezhetett a katona. Ezt a korabeli szaknyelv „Védletnek” nevezte. Ha az ellenség az első döfést csak cselnek szánta és a helyzetéböl kimozdított katonát a második döféssel kívánta megsebezni, akkor úgynevezett „Kettős védletet” kellett alkalmazni. Ez adta a szuronyharcra történő kiképzés későbbi alapjait a közbiztonsági szolgálatban is. A fentieket kötelékben úgy kellett végrehajtani, hogy a katonák egymástól egy lépésnyi távolságra álltak. ${ }^{49}$

A karhatalmi feladatok során alkalmazott kötelékmozgások elődje szintén tetten érhető a korai katonai szabályzatokban. A szuronyharcra kész kötelékben álló katona „Haladj” vezényszóra bal lábát elöre helyezte, majd jobb lábát utána vonta az állás megtartásával. „Hátrálj” vezényszóra ezt fordított 
sorrendben hajtotta végre. Ezeket a mozzanatokat kellett végrehajtani a „Sebesen haladj” és a „Sebesen hátrálj” vezényszóra is. Ez lehetővé tette a vonalalakzat fenntartását és kisebb ütemü térnyerést a kiszorítások során.

A szuronytámadás katonai változatának alapja az ellenség megsemmisítése volt lehetőleg halálos döféssel. Az „Egyenesen döfj!” vezényszóra végrehajtott döféskor a jobb térd kiegyenesedett, a bal lábat pedig úgy kellett behajlítani, hogy a bal térd a lábhegyével egy vonalba kerüljön, ezközben a jobb kezet a csípő mögé kellett emelni a jobb váll pedig elöre mozgott a döfés erejének megadására. A puska a jobb kézben előrenyúlt, a bal kéz pedig az egyensúly fenntartása miatt hátranyúlt. A puskát úgy kellett tartani, hogy a szurony hegye az ellenfél mellének mutasson. Az eröteljes szúrás közben a puskát a jobb kéz erősen tartotta, a bal kézben pedig a döfés közben elöre csúszott. Döfés után a katona gyorsan újra vívni állásba helyezkedett. ${ }^{50} \mathrm{~A}$ garantáltan halálos döfés technikáját azonban a közbiztonsági alkalmazáshoz finomítani kellett, ennek megfelelően a csendőrkötelék lehetőség szerint csak végtagot, elsősorban fegyvert tartó végtagot támadhatott a szuronytámadás során és harcképtelenné tételre, sebesítésre kellett törekednie, nem pedig halálos seb ejtésére. Ha figyelembe vesszük a szuronyfegyver alkalmazásának korabeli célját, vagyis a tömeg megriasztását, kimozdítását, ezáltal az aktív ellenszegülők kiemelését, a technika kellő kiképzéssel alkalmas volt a karhatalmi cél elérésére.

A karhatalmi kötelék azonban nemcsak támadásban, hanem végső esetben védekezésben is használta a szuronyvívás fogásait. A szurony a kötelékre támadó felböszült tömeg elleni azonnal rendelkezésre álló fegyver volt, bár a korabeli szakirodalom a karhatalmi erő biztonságát elsősorban lőfegyverhasználattal javasolta garantálni. A védekezés alapvetően a „Jobbra fedezz” és a „Balra fedezz" katonai vezényszavak által leírt technikákon alapult. A jól kiképzett katona az alakzatot megtartva ekkor a puskát felemeli és mindkét karjával balra vagy jobbra oldalt löki, ezáltal eltéríti az ellenség döfését vagy ütését. A támadás megtörését a védekező technika szuronytámadássá fejlesztése jelenthette, melyet a karhatalmi kötelék a tömeg kiszorítására használhatott ki.

Összefoglalva tehát a szuronyfegyver mai szemmel nézve brutális alkalmazásának komoly elméleti alapjai voltak a közbiztonsági szolgálatban. A fegyverhasználat azonban nem volt elkerülhetetlen velejárója a karhatalmi erö kivonulásának. Számos példa mutatja, hogy feldühödött tömeggel szemben is célravezető lehetett a békés, pusztán a csendőrség tekintélyét kihasználó tömegoszlatás, ami az emberek „kikísérését” jelentette az adott területről. A korszak karhatalmi kiképzésének legnehezebb feladata a legénység stressztürö képességének növelése, a higgadt fellépés elérése volt. Ez a Csendőrségi Lapok csaknem mindegyik témával foglalkozó szakcikkében megjelenő probléma. A fezült helyzetekben a csendőrök nyugalomra intésének alapvető mottóját SoLTÉSz Imre fogalmazza meg találóan: „Az életét is pellengérre állitó lázadóban tekintsük a családapát, $s$ mérséklettel, ésszel igyekezzünk lecsillapítani annak lángoló szenvedélyeit és indulatait." ${ }^{51}$

\section{Löfegyverhasználat}

A csapaterős karhatalmi szolgálatot teljesítő csendőrkötelék lőfegyver-használati jogára és ennek gyakorlatára külön szükséges kitérni, mivel ez a csendőrség általános lőfegyver-használati szabályaitól eltér. A csendőrségi karhatalom fegyveres erőszakot a Magyar Királyi Honvédség Szolgálati Szabályzatának 72. §-a szerint alkalmazhatott, míg a rendőri segélyt teljesítő csendőrjárőr fegyverhasználatára a Szervezeti Utasítás 11 . $\S$-a volt irányadó. ${ }^{52}$

A fegyveres erőszak zavargások elfojtására történő alkalmazását tehát a katonai és a csendőrségi karhatalom azonos szabályozás alapján hajtotta végre. Ennek esetei a következők szerint foglalhatók össze: $:^{53}$

1. Zavargásoknál és lázongó mozgalmaknál a felhatalmazott közigazgatási tisztviselő határozott és indokolt kérelmére akkor, ha a megelőző felhívások a törvényes állapot helyreállítására eredménytelenek maradtak és a közbelépés szükségességéröl a katonai parancsnok is meg van győződve.

2. Ha a kirendelt csapatot bántalmazzák, fegyverrel megtámadják, ha a tömeg fegyverekkel és ellenséges szándékkal nyomul a csapatok felé és attól lehet tartani, hogy müködésüket megakadályozzák vagy túlságosan korlátozzák.

3. Ha a közigazgatási tisztviselő nincs jelen akkor a csapat parancsnoka köteles a személy-, tulajdon, vagy a közintézmények biztonsága elleni támadás esetén a törvényes rend helyreállításra felhívást intézni, mely eredménytelensége esetén saját belátása szerint közbelépni.

A fenti esetekben is fennálltak azonban a fegyverhasználat szigorú korlátai, vagyis a „lehető kímélet" és a célzatosság elve. A lehető kímélet alatt az volt értendő, hogy a fegyvert használó csendőr 
szándékának csak arra szabadott irányulnia, hogy a támadót illetőleg ellenszegülőt a támadás folytatására vagy az ellenszegülésre, a szökni törekvő veszélyes gonosztevőt pedig a szökésre képtelenné tegye. ${ }^{54}$ A kíméletes fellépés másik eleme az volt, hogy a fegyverhasználatkor az öregek, asszonyok és gyermekek védelmére különös figyelmet kellett fordítani.

A célzatosság elve egyrészt abból állt, hogy a fegyverhasználatra jogosult és köteles csendör a fegyverét csak katonai módon használhatta. Eszerint a kard vágásra és csak kivételesen szükség esetén szúrásra, a feltüzött szurony szúrásra, a karabély és a forgópisztoly lövésre szolgált A fegyvereknek minden más, nem katonai alkalmazása tilos volt. Ettől csak a dulakodásba keveredett csendőrkötelék térhetett el, amikor is szükség esetén a karabély agya (tusa) vagy a kard markolata lökésre vagy ütésre is használható volt. Ezt azonban a karhatalmi köteléknek kerülnie kellett. A katonai módon történő fegyverhasználat alapvető feltétele volt az is, hogy a csendőrök ne a levegőbe löjenek, hanem a föcinkosokat és felbujtókat vegyék célba, de csak azokat, akiknél valóban fegyver van. Ha a kődobálásról nem volt megállapítható, hogy a tömegböl jött volna, a csendőrségnek nem volt joga fegyvert használni. Mivel azonban a karhatalmi fellépést elsősorban harcfeladatként fogták fel fontos kiemelni, hogy ha a támadó látható és azonosítható volt akkor is célba lehetett venni, ha körülötte mások is tartózkodtak. ${ }^{\mathbf{5 5}}$

A Magyar Királyi Honvédség Szolgálati Szabályzata szintén összefoglaló jelleggel említi a fenti korlátozásokat. Megfogalmazása szerint az egyes kihívások, valamint a felizgatott tömeg kiabálása és fütyülése folytán - amelyet a népzavargásoktól rendszerint elmaradhatatlannak tartottak - a csapat nem ragadtathatta magát azonnal a fegyver használatára, különösen a tüzelésre, addig amíg az ellenséges megnyilvánulások a csapatra nézve veszedelmes következményekkel nem jártak. ${ }^{56} \mathrm{Ha}$ azonban a lőfegyverhasználat szükségessé vált, a csapatnak a csendzavarók teljes szétoszlását vagy feltétlen megadását kellett követelnie és semmi szín alatt sem szabadott alkudozásba bocsátkoznia. A fegyverhasználati jog minden túlhágásáért az egyes csendőr is szigorú felelősséggel tartozott. A csapatból vezényszó nélkül leadott lövést jogtalan fegyverhasználatként kellett elbírálni.

\section{Összegzés}

A vizsgált időszakban a magyar rendvédelmi struktúra nem volt karhatalmi tevékenységre koncentrált, különösen nem a csapaterös rendvédelmi teendők tekintetében. Ennek ellenére a kor színvonalán álló, sőt esetenként azt meg is haladó taktikai eljárások és szabályzatok kidolgozására került sor, melyeket sikerrel alkalmaztak. A vizsgált időszakban a magyar gyakorlat azt a történelmileg jól bevált és takarékos megoldást követte, hogy szükség esetén a véderö alakulatait is alkalmazták nagyobb létszámú, vagy egyszerre több helyen megvalósításra kerülő csapaterős karhatalmi feladat teljesítésére, mivel ilyen helyzetek ritkán álltak elő. A jogi szabályozás és a polgári állam fejlődésével azonban mindinkább előtérbe került a rendvédelmi karhatalom alkalmazása, melynek az a tény kedvezett leginkább, hogy a Magyar Királyi csendörség jellegénél fogva alkalmas és képes volt a feladat végrehajtására. A normatív szabályozás katonai taktikák közbiztonsági átültetésén alapult, ezért mind a professzionális csendőri, mind a sorállományú kiképzésen átesett katonai erő számára jól alkalmazhatóak voltak.

A közigazgatási struktúrából és a rendfenntartásra vonatkozó korabeli felfogásból adódóan a karhatalom és határterületei ezer szálon kötődtek a polgári hatóságokhoz, így fellépésük folyamatos kontroll alatt állt. A jól szabályozott és számos garanciát tartalmazó normarendszer folyamatosan alkalmazkodott a társadalmi viszonyok változásához és a csendőrségi szervezet - ezen belül is a karhatalmi kötelékek - rugalmasan alkalmazkodtak a megváltozott követelményekhez. A csapaterős karhatalmi feladatok gyakorlati végrehajtási technikáinak és taktikai eljárásainak fentiekben bemutatott alapjai máig tetten érhetők a rendőrségi csapatszolgálati szabályzatban és kiképzési irányelvekben.

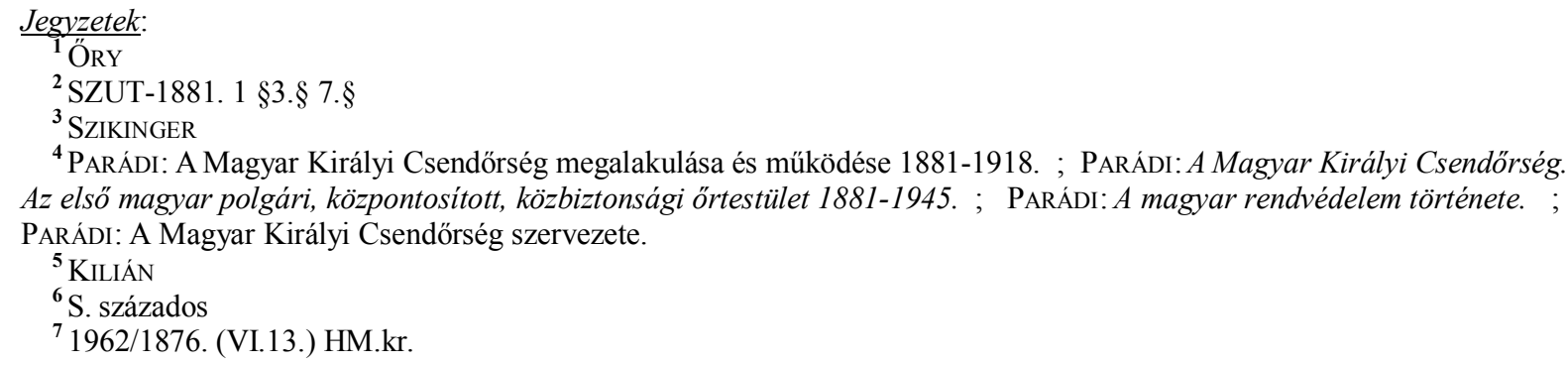


8 4539/1886. (I.16.) HM.kr.

${ }^{9}$ 6707/1896. (X.23.) HM.r. ; 58 440/1896. (XI.25.) IM.r.

${ }^{10}$ SZUT-1912.

${ }^{11}$ KAISER

${ }^{12}$ BORBÉLY — KAPY: 111-115.p. ; PARÁDI: A dualizmus közrendvédelmi szerveinek jellemzői és tevékenységük tapasztalatai.

${ }^{13}$ PARÁDI: A magyar rendvédelem fejlesztési reformjai a XIX. század második felétől a XX. század közepéig.

${ }^{14}$ SÁNDOR

${ }^{15}$ SUBA

${ }^{16}$ PRESZLY

${ }^{17}$ Berkó ; RAvasz: A Magyar Királyi Honvédség karhatalmi jogosultságai. ; RAvasz: A Magyar Királyi Honvédség karhatalmi alkalmazásának szabályozása a Horthy korban.

${ }^{18}$ SOLTÉSZ I.rész.

${ }^{19}$ SZUT-1912. op.cit. $76 . \S$

${ }^{20}$ SOLTÉSZ: op.cit. II.rész.

${ }^{21}$ Loc.cit.

22 1903/V.tc.

${ }^{23}$ Csendörségi SZUT magyarázata: 27.p.

${ }^{24}$ Loc.cit. 79.p. 68.§

${ }^{25}$ Loc.cit. 28.p.

${ }^{26}$ Szolgálati szabályzat a Magyar Királyi Honvédség számára. 248.p. XI. fejezet A közrend és közbiztonság fenntartása

70.§ Karhatalom.

${ }^{27}$ Loc.cit. 251.p. 71.§ Magatartás fölkelés vagy lázongás előtt és alatt.

28 „A honvéd állomás parancsnok van hivatva arra, hogy a törvények tekintélyének megóvására és a közcsend és rend fenntartására, az állomás szolgálati körében az ott elhelyezett honvéd csapatok által . . . a kormánynak biztos támaszául szolgáljon."

Loc.cit. 217.p. 441.pont.

${ }^{29}$ Loc.cit. 514.pont.

${ }^{30}$ SZUT-1900. 137.p. 31.§

${ }^{31}$ SZUT-1881. op.cit. 77.§

${ }^{32}$ Szolgálati szabályzat a Magyar Királyi Honvédség számára. op.cit. : 515.p.

${ }^{33}$ S. százados. : op.cit. 148.p.

${ }^{34}$ PAJOR: 277.p.

${ }^{35}$ Loc.cit.

${ }^{36}$ Szolgálati szabályzat a Magyar Királyi Honvédség számára. op.cit. : 244.p. 68.§ Sorfalak.

${ }^{37}$ Loc.cit. 498.pont.

${ }^{38}$ Loc.cit. 499.pont.

${ }^{39}$ Loc.cit.

${ }^{40}$ SZUT-1900. op.cit. 177.p. $68 . \S$

${ }^{41}$ Szolgálati szabályzat a Magyar Királyi Honvédség számára. op.cit. : 519.pont.

${ }^{42}$ Csendörségi SZUT magyarázata: op.cit.

${ }^{43}$ Szolgálati szabályzat a Magyar Királyi Honvédség számára. op.cit. : 162.p. 45.§ Különítmények és szállítmányok.

${ }^{44}$ GÁL: 8.p.

45 Loc.cit. 21.p.

${ }^{46}$ Gyakorlati szabályzat a Magyar Királyi Honvéd gyalogság számára. 32.p.

${ }^{47}$ Loc.cit. 55.p. 9.§ A puskának döfö fegyverül használata.

${ }^{48}$ GÁL: op.cit. 14.p.

${ }^{49}$ Loc.cit. 29.p.

${ }^{50}$ Gyakorlati szabályzat a Magyar Királyi Honvéd gyalogság számára. op.cit. 55.p. 9.§ A puskának döfő fegyverül használata.

${ }^{51}$ SOLTÉSZ : op.cit. I.rész. 350.p.

${ }^{52}$ S. százados. op.cit.

${ }^{53}$ Szolgálati szabályzat a Magyar Királyi Honvédség számára. op.cit. : 72.§

${ }^{54}$ SZUT-1900. op.cit. 168.p. 64.§

${ }^{55}$ Csendörségi SZUT magyarázata. op.cit. : 27.p.

${ }^{56}$ Szolgálati szabályzat a Magyar Királyi Honvédség számára. op.cit. : 517.pont.

\section{A jegyzetekben alkalmazott röviditések:}

\section{MONOGRÁFIÁK, KISMONOGRÁFIÁK ÉS HASONLÓ JELLEGÜ KÖTETEK}

BERKÓ

BORBÉLY - KAPY

\section{TANKÖNYV}

GÁL
- Berkó István (szerk.): A Magyar Királyi Honvédség története 1868-1918. Budapest, 1928, Magyar Királyi Hadtörténelmi Levéltár. 92 p.

- BorbéLy Zoltán - KAPY Rezső (szerk.): A 60 éves magyar rendörség 1881-1941. Budapest, 1942, Halász Irodalmi és Könyvkiadó Vállalat. I.köt. 1299.p. , II.köt. 300-594.p.

- GÁL Sándor: Szuronyvítan a gyalogság számára. Pest, 1848, Kozma Vazul. $30 \mathrm{p}$. 


\section{KAISER}

PARÁDI: A magyar rendvédelem története.

PARÁdI : A Magyar Királyi Csendörség. Az elsö magyar polgári, központositott, közbiztonsági örtestület 1881-1945.

PRESZly

\section{TANULMÁNYOK}

ÖRY

PARÁDI József: A magyar rendvédelem fejlesztési reformjai a XIX. század második felétől a XX. század közepéig

PARÁDI József: A dualizmus közrendvédelmi szerveinek jellemzői és tevékenységük tapasztalatai

PARÁDI: A Magyar Királyi Csendőrség megalakulása és müködése 1881-1918.

PARÁDI: A Magyar Királyi Csendőrség szervezete.

RAVASZ: A Magyar Királyi Honvédség karhatalmi jogosultságai.
- KAISER Ferenc: A Magyar Királyi Csendörség története a két világháború között. Pécs, 2002, Pro Pannónia Kiadói Alapítvány. 175 p. HU-ISBN 96390 7982 0. /Pannon Könyvek./ HU-ISSN 0237-4277.

- PARÁDI József et. al. (szerk.): A magyar rendvédelem története. Budapest, 1995, Tipico Design Kft. 317 p. HU-ISBN 963046215 X.

- PARÁdi József: A Magyar Királyi Csendörség. Az elsö magyar polgári, központositott, közbiztonsági örtestület 1881-1945. Budapest, 2012, Szemere Bertalan Magyar Rendvédelem-történeti Tudományos Társaság. 281 p. HU-ISBN 978963084794 0. /A magyar rendvédelem-történet öröksége, 2./ HU-ISSN 20628447.

- Preszly Lóránd: A Magyar Királyi Csendörség története 1881-1919. Budapest, 1920, Honvédelmi Sajtóvállalat. 142 p.

- ÖRY Károly: A Maréchaussée-tól a Gendarmerie Nationale-ig. A Francia Nemzeti Csendőrség történelmi elözményei. Rendvédelem-történeti Füzetek (Acta Historiae Praesidii Ordinis), VII. évf. (1997) 8. sz. 75-77.p. HU-ISSN 1216-6774. A tanulmány korábbi változata 1996. október 29-én Budapesten hangzott el a Szemere Bertalan Magyar Rendvédelem-történeti Tudományos Társaság által szervezett magyar rendvédelem-történeti tudományos konferenciasorozatnak „A napóleoni közbiztonsági örtestület útja Párizstól Itálián és Ausztrián keresztül - Budapestig." címü VIII. konferenciáján. A tanulmány az előadás javított, bővített és átdolgozott változata.

PARÁDI József: A magyar rendvédelem fejlesztési reformjai a XIX. század második felétől a XX. század közepéig. Rendvédelem-történeti Füzetek (Acta Historiae Praesidii Ordinis), XV. évf. (2008) 18. sz. 98-112.p. HU-ISSN 1216-6774. A tanulmány korábbi változata 2004. október 13-án, Budapesten hangzott el a Szemere Bertalan Magyar Rendvédelem-történeti Tudományos Társaság által szervezett rendvédelem-történeti tudományos konferenciasorozatnak a „Karhatalmi feladatok a bünmegelözés és a békefenntartás szolgálatában Európában a XIX-XX. században." címü XVIII. konferenciáján. A publikált tanulmány az előadás javított, bővített és átdolgozott változata.

PARÁDI József: A dualizmus közrendvédelmi szerveinek jellemzői és tevékenységük tapasztalatai. Rendvédelem-történeti Füzetek (Acta Historiae Praesidii Ordinis), II. évf. (1992) 3. sz. 21-28.p. HU-ISSN 1216-6774. A tanulmány korábbi változata 1991. november 19-én, Budapesten hangzott el a Szemere Bertalan Magyar Rendvédelem-történeti Tudományos Társaság által szervezett rendvédelem-történeti tudományos konferenciasorozatnak a „Tradíció és korszerüség." című III. konferenciáján. A publikált tanulmány az előadás javított, bővített és átdolgozott változata.

PARÁDI József: A Magyar Királyi Csendőrség megalakulása és müködése 1881-1918. Rendvédelem-történeti Füzetek (Acta Historiae Praesidii Ordinis), VII. évf. (1997) 8. sz. 78-83.p. HU-ISSN 1216-6774. A tanulmány korábbi változata 1996. október 29-én Budapesten hangzott el a Szemere Bertalan Magyar Rendvédelem-történeti Tudományos Társaság által szervezett magyar rendvédelem-történeti tudományos konferenciasorozatnak „A napóleoni közbiztonsági örtestület útja Párizstól - Itálián és Ausztrián keresztül - Budapestig." címủ VIII. konferenciáján. A tanulmány az előadás javított, bővített és átdolgozott változata.

- PARÁdi József: A Magyar Királyi Csendőrség szervezete. Rendvédelemtörténeti Füzetek (Acta Historiae Praesidii Ordinis), XXI. évf. (2011) 24. sz. 80-90.p. HU-ISSN 1216-6774. A tanulmány korábbi változata 2009. december 3-án Budapesten hangzott el a Szemere Bertalan Magyar Rendvédelem-történeti Tudományos Társaság által szervezett magyar rendvédelem-történeti tudományos konferenciasorozatnak „Csendörség Ausztria-Magyarországon, illetve Ausztriában és Magyarországon 18492005. ” címü XXIV. konferenciáján. A tanulmány az előadás javított, bővített és átdolgozott változata.

RAVASZ István: A Magyar Királyi Honvédség karhatalmi jogosultságai. Rendvédelem-történeti Füzetek (Acta Historiae Praesidii Ordinis), V.évf. (1995) 6.sz. 81-88.p. HU-ISSN 1216-6774. A tanulmány korábbi változata 1994. októberében Budapesten hangzott el a Szemere Bertalan Magyar Rendvédelem-történeti Tudományos Társaság által szervezett magyar rendvédelem-történeti tudományos konferenciasorozatnak , A két világháború közötti Magyar Királyság rendvédelme." címü VI. konferenciáján. A tanulmány az előadás javított, bővített és átdolgozott változata. 
RAVASz: A Magyar Királyi Honvédség karhatalmi alkalmazásának szabályozása a Horthy-korban.

SuBA

SZIKINGER

\section{CIKKEK}

KILIÁN

PAJOR

S. százados

SÁNDOR

SOLTÉSZ

\section{SZABÁLYZATOK}

SZUT-1881.

SZUT-1900

SZUT-1912

A csendőrségi SZUT magyarázata.

Szolgálati Szabályzat a Magyar Királyi Honvédség számára.

Gyakorlati Szabályzat a Magyar Királyi Honvéd gyalogság számára.

\section{JOGSZABÁLYOK}

1903/V.tc.

1962/1876. (VI.13.) HM.kr.

4539/1886. (I.16.) HM.kr.

6707/1896. (X.23.) HM.kr.

58 440/1896. (XI.25.).IM.r.
- RAvasz István: A Magyar Királyi Honvédség karhatalmi alkalmazásának szabályozása a Horthy-korban. Hadtörténelmi Közlemények, CXIX. évf. (2004) 1. sz. 269-284.p. HU-ISSN 0017-6540.

- SubA János: Karhatalmi formációk Magyarországon 1918-1920. Rendvédelem-történeti Füzetek (Acta Historiae Praesidii Ordinis) XV. évf. (2008) 18.sz 131-142.p HU-ISSN 1216-6774. A tanulmány korábbi változata 2004. október 13-án Budapesten hangzott el a Szemere Bertalan Magyar Rendvédelem-történeti Tudományos Társaság által szervezett rendvédelemtörténeti tudományos konferenciasorozatnak a ,Karhatalmi feladatok a bünmegelözés és a békefenntartás szolgálatában Európában a XIX-XX. században." címü XVIII. konferenciáján. A publikált tanulmány az előadás javított, bővített és átdolgozott változata.

- SzIKINGER István: A rendvédelmi jog szabályozása a dualizmus korában. Rendvédelem-történeti Füzetek (Acta Historiae Praesidii Ordinis), III.évf. (1993) 4.sz. 187-198.p. HU-ISSN 1216-6774. A tanulmány korábbi változata 1992. szeptember 29-én, Budapesten hangzott el a Szemere Bertalan Magyar Rendvédelem-történeti Tudományos Társaság által szervezett rendvédelemtörténeti tudományos konferenciasorozatnak a „A dualista Magyarország rendvédelme." címü IV. konferenciáján. A publikált tanulmány az előadás javított, bővített és átdolgozott változata.

- KILIÁn Zoltán: Francia csendőrélet. Csendőrségi Lapok, XIX.évf. (1929) 19.sz. 571-573.p.

- PAJOR Tamás: Összpontosításoknál követendő eljárás. Csendőrségi Zsebkönyv, XXVI.évf. (1912.) 277-283.p.

- S. százados: A csendőrségi karhatalom Csendőrségi Lapok VII. évf. (1913) 13.sz. 145-148.p.

- SÁNDOR László: A csendőrségi szolgálat rendes és rendkívüli viszonyok között Csendörségi Lapok III. évf. (1909) 39.sz. 457-459.p.

- SoltÉsz Imre: A társadalmi harcokról. Csendörségi Lapok, I.évf. (1907) 30.sz. I. rész: 349-350 p. + II. rész: 31.sz. 361-363.p.

- A belügyi- és honvédelmi m. kir. minister által 1881. október 1-én, a m.kir. csendőrség számára kiadott szervezeti és szolgálati utasítás. Magyarországi Rendeletek Tára, XV.évf. (1881) I.füzet 1167-1344.p.

- Szolgálati utasítás. Általános rész. Budapest, 1900, Pesti nyomda. 361 p.

- Utasitás a Magyar Királyi Csendőrség számára. Budapest, 1912, Várnay és Fia Municipia Kiadóhivatala. 384 p.

- A csendőrségi SZUT magyarázata. Budapest, 1909, Kaufman Á. és Fiai. $175 \mathrm{p}$.

- Szolgálati Szabályzat a Magyar Királyi Honvédség számára. (I: rész) az 1875. évi szolgálati szabályzat második kiadása. Budapest, 1915, Pallas Irodalmi és Nyomdai Részvénytársaság. 255 p.

- Gyakorlati Szabályzat a Magyar Királyi Honvéd gyalogság számára. (I. rész) Budapest, 1875, Pfeifer Ferdinánd. 250 p.

- 1903/V.tc. külföldieknek Magyar Korona országai területén való lakhatásáról.

- 1962/1876. (VI.13.) HM.kr. utasítás a sorhadi vagy honvédségi karhatalomnak igénybevétele alkalmával a közhatóságok részéről követendő eljárásról. Magyarországi Rendeletek Tára, X.évf. (1876) 1.füzet 285-289.p.

- 4539/1886. (I.16.) HM.kr. az utasítás a sorhadi, vagy honvédségi karhatalomnak igénybe vétele alkalmával a közhatóságok részéről követendő eljárásról kiadott 1962/1876.HM.kr. módosítása tárgyában. Magyarországi Rendeletek Tára, XII.évf. (1887) 1.füzet 22-29.p.

- 6707/1896. (X.23.) HM.kr. a karhatalom igénybe vétele alkalmával a polgári hatóságok által követendő eljárásra vonatkozó utasítás kiadása.

Rendeleti Közlöny a Magyar Királyi Honvédség számára, XXIII.évf. (1896) 36.sz. 223-225.p.

- 58 440/1896. (XI.25.).IM.r. a karhatalom igénybevétele tárgyában. Igazságügyi Közlöny, Vévf. (1896) 11.sz. 357.p. 